\title{
Healthcare Encounters Category
}

National Cancer Institute

\section{Source}

National Cancer Institute. Healthcare Encounters Category. NCI Thesaurus. Code

C123940.

A classification of healthcare encounters data. 